\title{
« Ausgrabungen in Sippar (Tell Abu Habbah) - Vorbericht über die Grabungsergebnisse der 24. Kampagne 2002 », BaM 36, pp. 157-224.
}

\section{Astrid Nunn}

\section{(2) OpenEdition}

\section{Journals}

Édition électronique

URL : http://journals.openedition.org/abstractairanica/15672

DOI : 10.4000/abstractairanica. 15672

ISSN : 1961-960X

Éditeur :

CNRS (UMR 7528 Mondes iraniens et indiens), Éditions de l'IFRI

Édition imprimée

Date de publication : 15 mai 2007

ISSN : 0240-8910

Référence électronique

Astrid Nunn, « «Ausgrabungen in Sippar (Tell Abu Habbah) - Vorbericht über die Grabungsergebnisse der 24. Kampagne 2002 », BaM 36, pp. 157-224. », Abstracta Iranica [En ligne], Volume 28 | 2007, document 83, mis en ligne le 18 septembre 2007, consulté le 25 septembre 2020. URL : http:// journals.openedition.org/abstractairanica/15672 ; DOI : https://doi.org/10.4000/abstractairanica. 15672

Ce document a été généré automatiquement le 25 septembre 2020.

Tous droits réservés 
« Ausgrabungen in Sippar (Tell Abu Habbah) - Vorbericht über die Grabungsergebnisse der 24. Kampagne 2002 », BaM 36, pp. 157-224.

\author{
Astrid Nunn
}

1 Les fouilles reprises en 2002 par l'Université de Baghdad dans l'antique Sippar, au nordest de la ziggurat, ont permis de trouver du matériel qui date essentiellement $\mathrm{du}$ second millénaire puis des époques néo-babylonienne et achéménide. Il s'agit de matériel courant comme céramique, perles et petites armes.

INDEX

Thèmes : 3.2.2. Pré-Achéménides et Achéménides

\title{
AUTEURS
}

\section{ASTRID NUNN}

Université de Munich 